\title{
A trade-off between mucocytes and bacteriocytes in Loripes orbiculatus gills (Bivalvia, Lucinidae): a mixotrophic adaptation to seasonality and reproductive status in a symbiotic species?
}

\author{
Roques Cécile ${ }^{1}$, Grousset Evelyse ${ }^{1}$, Troussellier Marc ${ }^{1}$, Hermet Sophie ${ }^{1}$, Le Carrer Johan ${ }^{2}$, \\ Sar Chamroeun ${ }^{3}$, Caro Audrey ${ }^{1, *}$
}

${ }^{1}$ Marine Biodiversity, Exploitation and Conservation (MARBEC), Univ Montpellier, CNRS, Ifremer, IRD, Montpellier, France

2 Martinique Natural Marine Park, Fort-de-France, France

${ }_{3}^{3}$ Montpellier Ressources Imagerie, Montpellier, France

* Corresponding author : Audrey Caro, email address : audrey.caro@umontpellier.fr

\begin{abstract}
:
In this study, we investigated the composition of the gill tissue relative to the reproductive status of the lucinid clam Loripes orbiculatus (sensus Poli, 1791) according to seasonal as well as biological parameters to provide insights into the physiological variability of this symbiotic bivalve. Temporal variation in population density was also studied. The species was investigated in Zostera noltii seagrass beds in the Thau lagoon $\left(43^{\circ} 26^{\prime} 52.27^{\prime \prime} \mathrm{N}, 3^{\circ} 39^{\prime} 6.25^{\prime \prime} \mathrm{E}\right)$ in the south of France in a monthly sampling study from May 2013 to July 2015. A total of 257 individual adults of different sizes were analysed according to water temperature and salinity variations. The findings revealed a very stable Loripes density over time, with one single reproductive period during late spring/early summer. We also found that bacteriocytes and mucocytes in the gills were negatively correlated and highly variable in their respective proportions. Bacteriocytes remained dominant during cold periods, whereas mucocytes appeared mainly in the gills of large individuals when the water temperature increased in the spring. As mucocytes were also related with gonadal maturation, we hypothesize that these may allow the host to increase the proportion of heterotrophy in its nutrition during spring primary production to face the metabolic demands required for reproduction. It is possible that mucocytes may also be involved in host immunity.
\end{abstract}


Lucinid clams are benthic bivalves that live in seagrass beds in coastal tropical or temperate areas (van der Heide et al. 2012). These bivalves host sulphur-oxidizing chemoautotrophic endobacteria in large cells called bacteriocytes located in the gills (Felbeck et al. 1981), as has been described for Loripes (Herry et al. 1989). The gills of symbiotic species are thickened, which is related to the dominance of bacteriocytes in the gill tissue and represents an adaptation process to intracellular symbiosis. This symbiosis allows the bivalve's colonization of seagrass sediment, conditions that are generally toxic for most invertebrates due to the high level of sulphide, which originates from the anaerobic decomposition of organic matter by sulphate-reducing bacteria at the bottom of seagrass bed sediments. The endosymbiotic bacteria in the clam's gills use sulphide to fuel their own metabolism, i.e. to synthesize sugar compounds after $\mathrm{CO}_{2}$ fixation (van Dover 2000; Stewart et al. 2005). These compounds are then transferred to the host as an important source of nutrition (Distel and Felbeck 1987; Cary et al. 1989). Where lucinids are present, they mitigate sulphide stress in seagrass (van der Geest et al. 2020); indeed, the sulphur-oxidizing metabolism of endosymbionts can result in removing $2-16 \%$ of total sulphide in seagrass sediment (Reynolds et al. 2007), which is beneficial to ecosystem function (van Gils et al. 2012). Van der Heide et al. (2012) described the positive effects for all partners in the endosymbiont-host-seagrass relationship as 'threestage symbiosis', highlighting the ecological importance of lucinids for seagrass conservation (Johnson et al. 2002).

Estimates of the chemoautotrophic contribution to the host's carbon requirements generally reveal a high contribution - on average, 70\% - from symbionts (through the translocation of sugars in a process called 'milking'), with some variation according to season, size of the host, reproductive period, etc. (Cary et al. 1989; Dando and Spiro 1993; Le Pennec and Beninger 2000; Rossi et al. 2013; van der Geest et al. 2014). Moreover, as has been shown in starvation experiments, in addition to milking, the host's metabolic requirements can be ensured by the intracellular digestion of symbionts by host cell lysosomes in a process called 'farming' (Kádár et al. 2008; Caro et al. 2009; König et al. 2015). However, most lucinids have a mixotrophic diet, allowing them to feed either on symbiotic carbon (by milking or farming) or on particulate organic carbon (Le Pennec et al. 1988; Johnson and Fernandez 2001; Duplessis et al. 2004). Recently, it was shown that the endosymbionts of lucinids can also contribute to the nitrogen metabolism of the host ( $\mathrm{Ca}$. Thiodiazotropha endoloripes and Ca. Thiodiazotropha endolucinida were discovered as diazotrophic endosymbionts), in 
addition to the host's ability to use ammonium, urea and nitrate as a source of nitrogen (König et al. 2016; Petersen et al. 2016).

Loripes orbiculatus (previously known as Loripes lacteus), a bivalve abundant in the coastal lagoons of the south of France (Johnson et al. 2002; Carlier et al. 2009) and also present in Brittany (Herry et al. 1989; Johnson and Fernandez 2001), is one of these mixotrophic species. This species lives buried in the sediment of Zostera noltii seagrass beds (Lebreton et al. 2011), taking advantage of sulphides to fuel symbiont metabolism and dioxygen released by seagrass roots. Loripes orbiculatus also seems to be able to meet part of its metabolic requirements (an estimated 20\% to 70\%) by the ingestion and absorption of food particles in a process of heterotrophic nutrition (Johnson et al. 1996; Rossi et al. 2013; van der Geest et al. 2014). Diatoms are frequently found in its digestive system (Le Pennec et al. 1988), as is the case more generally in lucinids (Dando et al. 1986; Southward 1986; Herry and Le Pennec 1987; Duplessis et al. 2004), in spite of their reduced digestive tract (Allen 1958; Reid 1990; Le Pennec et al. 1995). Recently, molecular evidence has reinforced the pathway of heterotrophic nutrition, as enzymes able to digest complex polysaccharides from marine phytoplankton were shown at high levels in the visceral mass of Loripes orbiculatus (Yuen et al. 2019). All these characteristics are evidence of the ability of lucinids to feed on particles in the water column or benthic zone, even if carbon and nitrogen stable isotopic ratios remain low (which is typical of chemoautotrophic bivalves) and vary between individuals (Petersen et al. 2016). Thus lucinids are considered to be suspension and deposit feeders, in addition to their symbiotic mode of nutrition (Duplessis et al. 2004; Rossi et al. 2013; van der Geest et al. 2014).

The ability of suspension-feeding bivalves to collect and process particulate foods is generally associated with the mucus secreted by mucocytes located in the gills, labial palps, digestive tract, etc. In different suspension-feeding bivalves (Pectinidae, Ostreidae, Mytilidae), the types, distribution and density of mucocytes in the gills give indications of the latter's functional role, especially in terms of particle processing (Beninger et al. 1993; Dufour and Beninger 2001). Acid-secreting mucocytes are generally involved in collecting particles on the gill surface and transporting them to the ventral groove via the ciliated zone, forming a 'particle cord' that is conducted to the anterior labial palps (when present) for either ingestion or rejection as pseudo-faeces (Beninger and Dufour 1996; Beninger et al. 1997). The molecular role of mucus in the capture of food particles has been evidenced by the identification of lectins, isolated from the mucus of oysters (Crassostrea virginica) and 
mussels (Mytilus edulis); this lectin is involved in the interaction between carbohydrates found at the surface of microalgae and the mucus (Pales-Espinosa et al. 2009, 2010a, 2010b). However, little attention has been paid to the distribution and density of mucocytes in the gills of symbiotic bivalves; mucocytes have often been reported as scarce cells, interspaced among the bacteriocytes (reviewed in Duplessis et al. 2004; Pales-Espinosa et al. 2013b). Only a few studies on lucinids have investigated the distribution and potential function of these mucocytes regarding the filtration process (Duplessis et al. 2004).

Beyond the role of mucus in particle capture for host nutrition, it also represents the first line of defence to fight harmful microbes in marine invertebrates. The structure and composition of the mucus covering the body surface in invertebrates influence its effectiveness in immunity; mucin matrices contain a large variety of bioactive molecules such as lysozymes, antimicrobial peptides (Vidal-Dupiol et al. 2011, Destoumieux-Garzon et al. 2016, RiveraOrtega and Thomé 2018), and adhesion molecules such as lectins and agglutinins (Xing et al. 2011; Pales-Espinosa et al. 2016). The diversity of immune effectors found in mucus allows a tailored immune response (Allam and Pales-Espinosa, 2016) according to the type of hostmicrobe association. In bivalves, mucosal secretions, in addition to cellular immunity, help the host to fight off diseases caused by various types of bacteria (Allam and Pales-Espinosa 2016, Travers et al. 2015), viruses (Arzul et al. 2017) and protozoans (Pales-Espinosa et al. 2013a). Moreover, mucus could favour a specific symbiont, as seen in some lucinid bivalves through a C-type lectin (Gourdine and Smith-Ravin 2007) or in the association between Vibrio fischeri and the squid Eupryma scolopes (Nyholm and McFall-Ngai 2003).

The primary objective of this study was to investigate the gill tissue composition of Loripes orbiculatus (sensu Poli 1791), with a focus on the seasonal dynamics of mucocytes and bacteriocytes, through a quantitative histological analysis. The second objective was to decipher the environmental and biological factors responsible for gill plasticity in this species. The environmental variables investigated were water temperature and salinity; the biological factors considered were the different areas of the gills (on an anterior to posterior axis), and the size and sex of individuals.

\section{Materials and methods}

\section{Sampling of the bivalves}


The survey was conducted in the Mediterranean Thau lagoon in the south of France near the oyster-farming village of Bouzigues (4326'52.27" N, $3^{\circ} 39^{\prime} 6.25^{\prime \prime} \mathrm{E}$ ). The symbiotic clam Loripes orbiculatus (hereafter Loripes) was collected between May 2013 and July 2015. These bivalves are located at a depth of 5 to $10 \mathrm{~cm}$ in the sediment surrounding the roots of the seagrass Zostera noltii. They were collected by hand using a PVC cylinder $(12 \mathrm{~cm}$ diameter, $20 \mathrm{~cm}$ high). Once a month, 10 sediment cores were randomly collected in the seagrass meadows and sieved over a $3 \mathrm{~mm}$ mesh. From one month to another, we carefully avoided collecting Loripes in the same area, but samples were always collected in the same meadow. The survey was divided into two periods for a total of 26 months of sampling: (1) from May 2013 to October 2014, the total number of Loripes collected per core was recorded and the monthly data from the 10 sediment cores was used to calculate the mean and standard deviation of Loripes density (number of individuals $\mathrm{m}^{-2}$ ); (2) from February 2014 to July 2015, adult bivalves (> $7 \mathrm{~mm}$ ) were collected for histological investigation and sorted into three size classes: small adults $(7-8 \mathrm{~mm})$, medium adults $(9-10 \mathrm{~mm})$ and large adults $(>12$ $\mathrm{mm})$. For each sampling month, 5 to 10 adults were selected in each size class to perform histological analyses, amounting to a total of 257 analysed individuals.

\section{Bouin's fixative and staining}

The bivalves selected for analysis for each size class were carefully dissected to keep the visceral mass (gonad-digestive gland complex) and the gills associated. Entire specimens extracted from the shell were fixed in Bouin's fixative for $48 \mathrm{~h}$, then rinsed daily in ethanol (70\%) until discoloration of the tissue. After dehydration in an ascending ethanol series, the whole soft tissue was then embedded in a Paraplast block and cut into serial transverse sections (7- $\mu \mathrm{m}$ thick) along an anteroposterior axis, midway between the dorsal part of the gills and the ventral groove. The sections were stained with Masson's trichrome (Gabe 1968): bacteriocytes were stained pink or purple, depending on the individual, whereas mucocytes were non-specifically stained light blue.

As several types of mucocytes exist, the identification of mucocytes was performed on some individuals with Periodic Acid-Schiff-Alcian Blue (PAS-AB) staining. This method specifically focuses on mucopolysaccharides, making acid-secreting mucocytes appear intensely blue-stained, whereas bacteriocytes and ciliated zones appear weakly pink-stained (Beninger et al. 2003). 


\section{Image analysis}

162 The Masson's trichrome-stained sections of the whole tissue (i.e. visceral-gonadal mass

163 joined to both gills) were scanned with a NanoZoomer (MRI Platform, Montpellier) for

164 further image analysis of the gill tissue composition (see below) and sexual determination.

165 After microscopic examination of the visceral-gonadal mass, individuals were classified as

166 male based on the presence of spermatogonia or spermatozoid (Fig. 2d) or as female when

167 oogonia or oocytes were present (Fig. 2f). When any gametes were visible, the individuals

168 were classified as 'not determined'. In the gill analysis, three specific regions were

169 investigated: anterior ('Ant'), median ('Med') and posterior ('Post') regions (Fig. 2a).

170 For the gill tissue analysis, we used Definiens Developer 7.1 software (Definiens, Munich,

171 Germany) to quantify the proportions of the different parts of the gills. The ciliated zone was

172 included in the analysis as it is an integral part of the gill. First, 6 gill filaments were manually

173 outlined using 'Paint' free software to determine the total area of the analysed gill region in

174 order to standardize the gill surface area between individuals of varying sizes (See Electronic

175 Supplementary Material, ESM, Fig. S1). Then, Definiens was used to measure, in pixels, the

176 surface area of the two ciliated zones (CZ) and the central zone (ESM, Fig. S1a). In the

177 central zone, Definiens was used to build a set of rules to distinguish different types of cells or

178 spaces ('areas') in the stained sections: light blue for mucocytes (MC), pink/purple for

179 bacteriocytes (BC) and white (unstained) for lacunal/interfilamentar space (LIS) (ESM, Fig.

180 S1b). The different surface areas (BC, MC, CZ and LIS) were used to calculate the

181 proportions (as percentages) of bacteriocytes, mucocytes, ciliated zone and

182 lacunal/interfilamentar space in the gill tissue. These proportions were investigated in 239

183 Loripes individuals (out of the 257 collected), generating 647 gill images. This would have

184 yielded a total of 717 images (three gill regions - Ant, Med, Post - per individual), but some

185 images were not usable.

\section{Statistical analyses}

188 Descriptive statistics (mean, standard deviation, coefficients of variation) were calculated 
190 tests were calculated using XLSTAT software (Addinsoft 2019, Paris, France,

191 https://www.xlstat.com).

192

193 Results

194 Population density and reproductive cycle

195 From May 2013 to October 2014, the mean Loripes density in seagrass sediment was in the 196 order of $3395 \pm 195$ individuals $\mathrm{m}^{-2}$, ranging from 2509 to 3445 (Fig. 1a). 
a

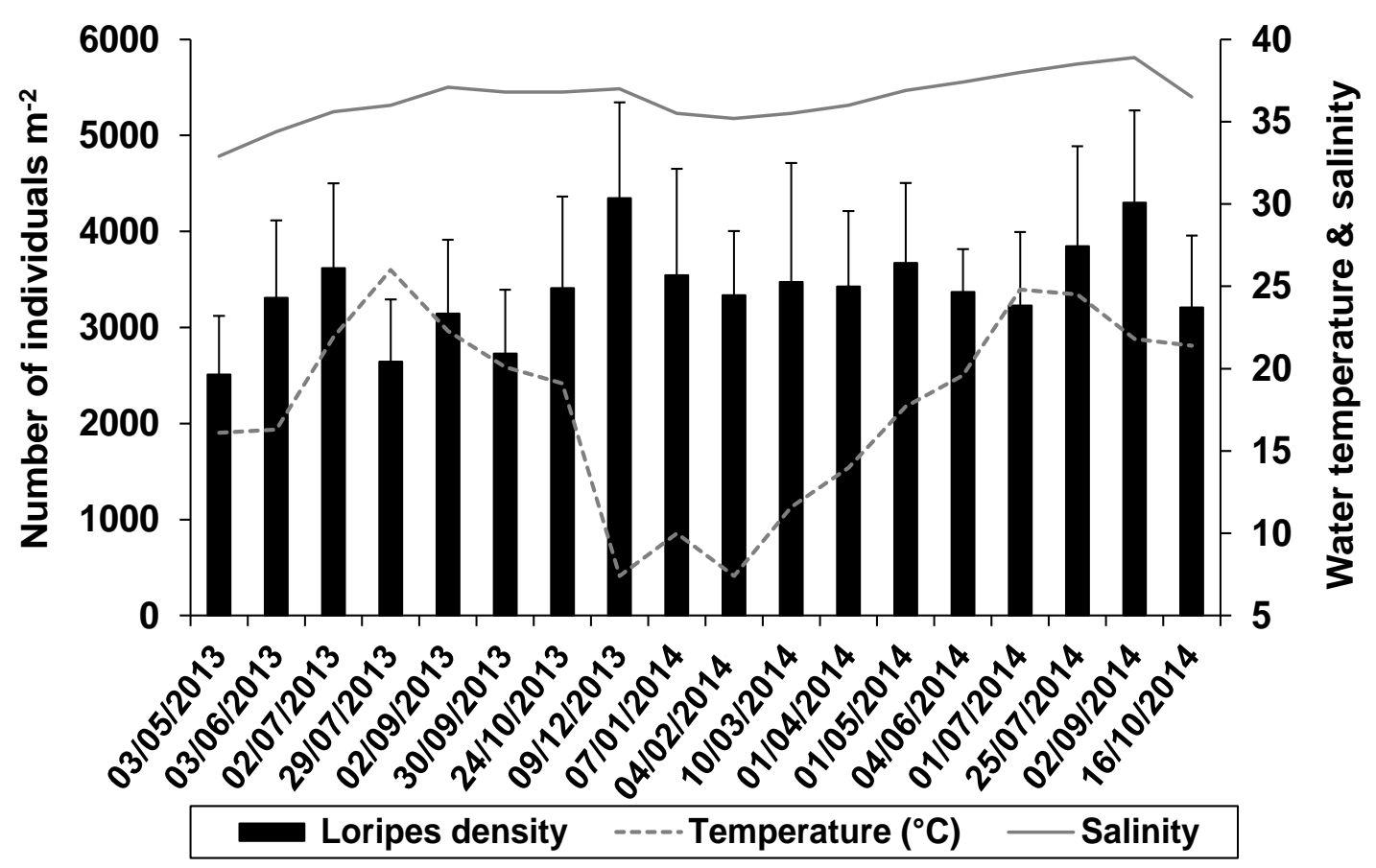

b

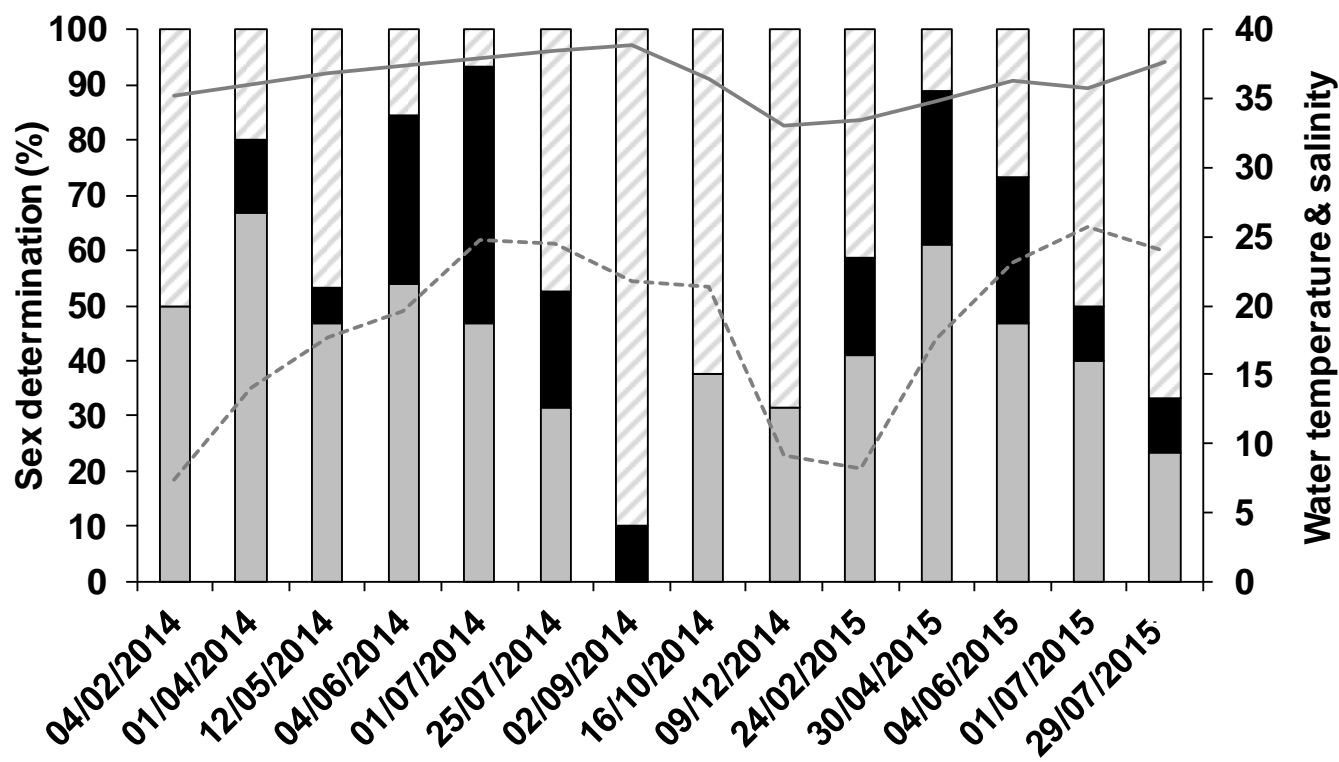

$\square$ Female $\square$ Male $\square$ Not determined - Salinity $\cdots$ Temperature $\left({ }^{\circ} \mathrm{C}\right)$

Fig. 1 Mean Loripes density in the Thau lagoon from May 2013 to October 2014 in relation to water temperature and salinity (a). Reproductive cycle based on sex determination throughout the sampling period (from February 2014 to August 2015) (b). Females were identified from oogonia or oocyte detection in the gonad, whatever the development stage; males were identified from spermatogonia or spermatozoa detection. The 'not determined' status corresponds to spent gonads after spawning (Seed 1969) or immature gonads. 
205 This density remained quite stable over the sampling period, whereas the water temperature 206 varied greatly, from $7.4{ }^{\circ} \mathrm{C}$ in winter to $26{ }^{\circ} \mathrm{C}$ in summer. Conversely, low variation was 207 observed for salinity in the same period (from 32.9 in May 2013 to 38.9 in September 2014).

208 To investigate the reproductive cycle of Loripes, sampling was performed from February 2092014 to August 2015 on the three size classes used for histological investigations. For this 210 analysis, all size classes were pooled together, as even the smallest class included individuals 211 able to reproduce (van der Geest 2014). The distribution of sexually determined individuals 212 (see Fig. 2d for male and 2f for female) showed a clear annual gametogenesis cycle (Fig. 1b).

213 The percentage of sexually determined individuals reached a maximum in the beginning of 214 July 2014 and at the end of April 2015 (Fig. 1b). These periods were immediately followed by 215 a substantial decrease in the percentage of sexually determined individuals during summer 216 (from June-July to September), corresponding to individuals with spent gonads. This indicates 217 that spawning probably occurred in late spring/early summer. Personal observations in 2017 218 and 2018 confirmed the presence of egg masses (the consequence of spawning) in seagrass 219 beds at the beginning of July on the same site.

221 Description of the gill tissue components

222 The gills of Loripes consist of two demibranches, one located on each side of the visceral223 gonadal mass (Fig. 2a). 
a

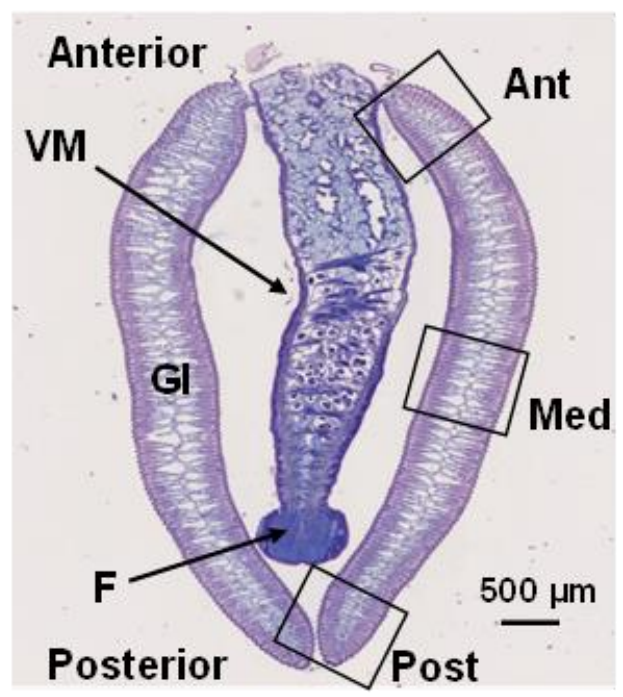

C

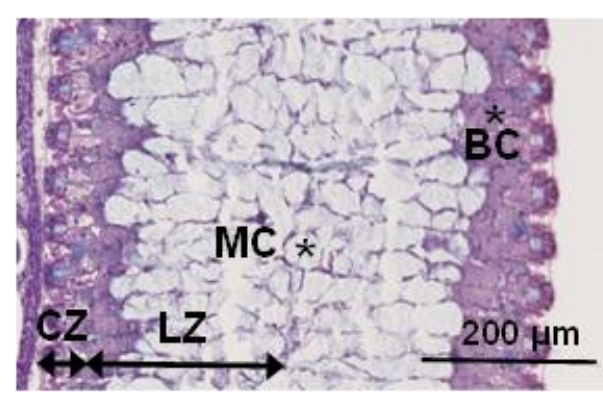

e

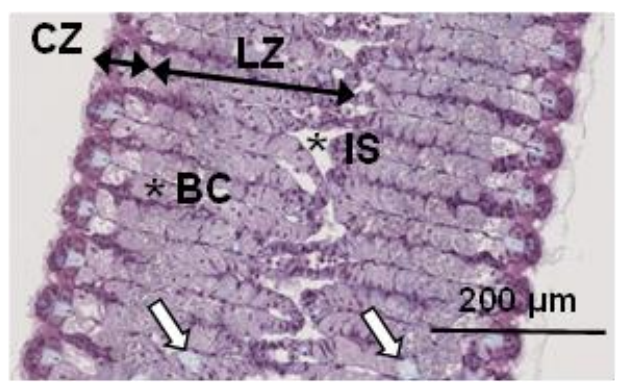

g

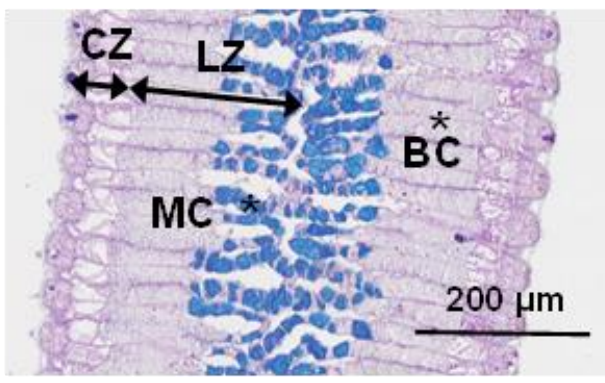

b

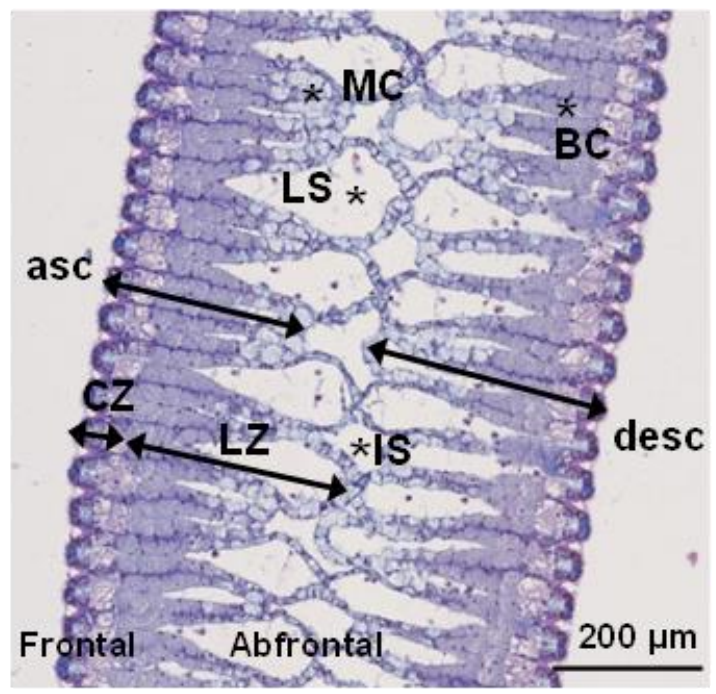

d

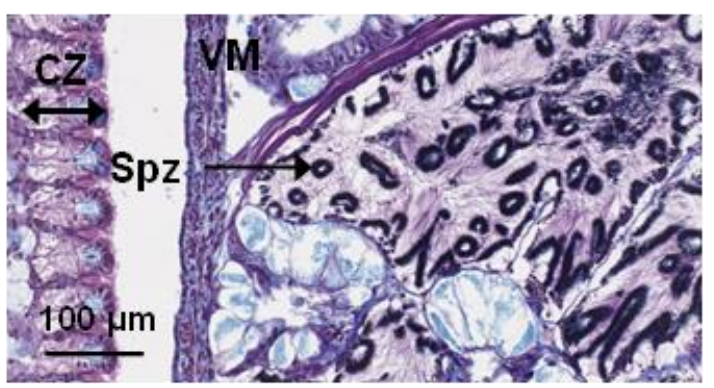

f

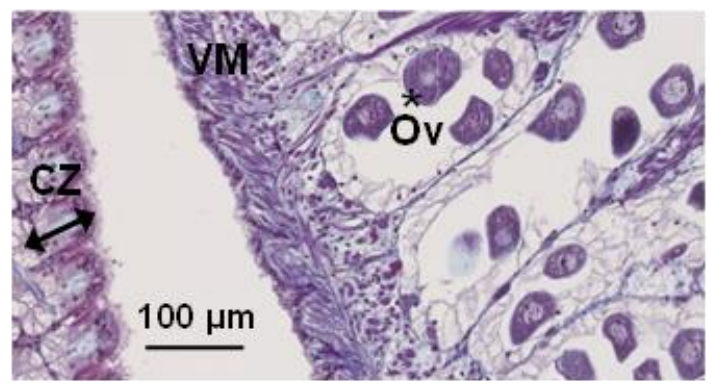

h

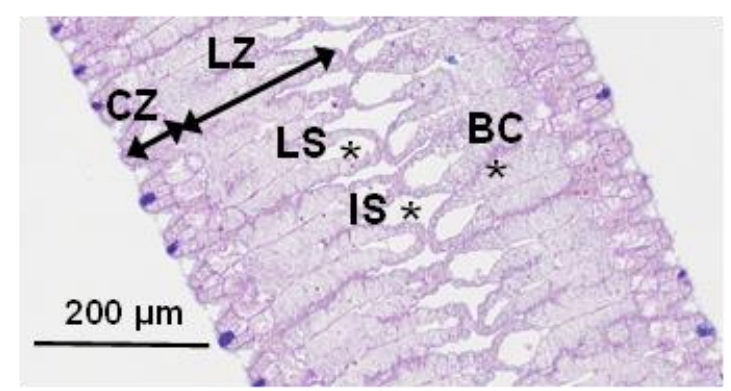

Fig. 2 Light micrographs of Loripes tissue after Masson's trichrome (from $\mathbf{a}$ to $\mathbf{f}$ ) and PAS-AB (g and $\mathbf{h}$ ) staining. (a) Transverse section of a whole individual showing the visceral-gonadal mass (VM) and the foot (F), surrounded by both demibranch gills (GI). Three different regions of the gills were investigated for image analysis: the anterior (Ant), the median (Med) and the posterior (Post) regions. (b) Magnification of the median gill section showing the ascending ('asc') and descending ('desc') lamella, separated by the interfilamentar space (IS); 
each lamella consists of a ciliated zone (CZ) (frontal position) and a lateral zone (LZ) (abfrontal position). The lateral zone is composed of bacteriocytes (BC), mucocytes (MC) and a lacunal space (LS). The variation in the gill histology between individuals is illustrated in (b), (c) and (e). Rare mucocytes in (e) are indicated by white arrows. A close-up of the visceral-gonadal mass with spermatozoids ('Spz'), typically organized in rings, is shown in (d), and with oocytes in (f), which allowed sex determination. In (g) and (h), PAS-AB staining shows mucocytes as blue cells $(\mathbf{g})$, whereas bacteriocytes are weakly stained in pink ( $\mathbf{g}$ and $\mathbf{h})$.

The digestive system and the gonads cannot be separated. Each gill is composed of an ascending and a descending lamella, with a ciliated zone and a lateral zone (Fig. 2b). The ciliated zone represents the gill's external surface, which is directly in contact with seawater circulating in the pallial cavity. The lateral zone occupies most of the gill tissue; its composition is highly variable between individuals. As shown in Fig. 2b, this lateral zone can be composed of bacteriocytes and mucocytes in variable proportions. Large bacteriocytes can be observed just under the ciliated zone, and thinner ones can be seen in the abfrontal part of the lateral zone (Fig. 2b, 2e). As illustrated in Fig. 2b, mucocytes are generally located deep inside the gill (in the abfrontal lateral zone), but in some rare cases they can totally invade the gill tissue (Fig. 2c) to the detriment of bacteriocytes. More frequently, mucocytes are totally absent from or rare in gill tissue (Fig. 2e). The type of mucocytes was determined with PAS$\mathrm{AB}$ staining of some individuals, with acid-secreting mucocytes identified in blue (Fig. $2 \mathrm{~g}$ ). Deep inside the gill (the abfrontal part of the filaments), two types of spaces can be observed: the interfilamentar space (IS), allowing the circulation of seawater throughout the gill from the ciliated zone to the abfrontal zone, and the lacunal space (LS) between the basal membrane of bacteriocytes or mucocytes. The lacunal space, which is dedicated to hemolymph circulation, often has a loop-like structure and is also highly variable in volume between specimens, as is the case for interfilamentar space.

\section{Quantification of gill tissue composition}

In order to quantify the different gill components described above and characterize their variability, we pooled the data from individuals in all class sizes (between 15 and 30 adults per month) and all gill regions (Ant, Med, Post) for the total sampling period (from February 2014 to July 2015). We calculated the mean value and standard deviation for each type of cell 
Table 1 Descriptive statistics relative to the proportions (\%) of bacteriocytes, mucocytes, lacunal/interfilamentar space and the ciliated zone $(\mathrm{N}=647)$ calculated over the total sampling period (from February 2014 to July 2015).

\begin{tabular}{lllll}
\hline & Bacteriocytes & Mucocytes & $\begin{array}{l}\text { Lacunal/inter- } \\
\text { filamentar space }\end{array}$ & Ciliated zone \\
\hline $\begin{array}{l}\text { Mean value } \pm \text { standard } \\
\text { deviation (SD) }\end{array}$ & $56.4 \pm 11.5$ & $7.6 \pm 12.6$ & $9.8 \pm 8.5$ & $26.2 \pm 5$ \\
\hline $\begin{array}{l}\text { Coefficient of variation } \\
(\mathrm{CV})\end{array}$ & 20 & 166 & 88 & 19 \\
\hline
\end{tabular}
Table 1).
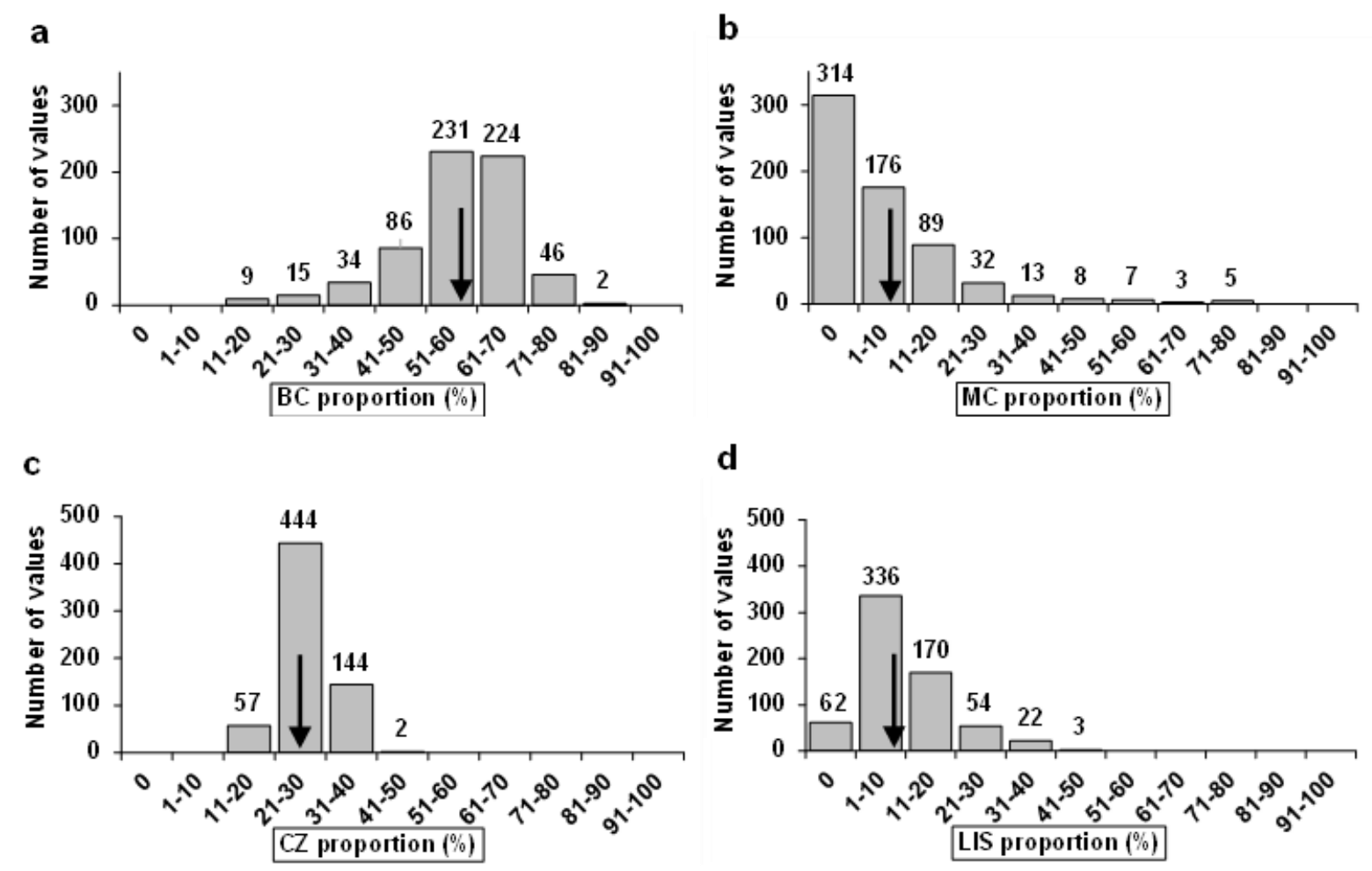

Fig. 3 Data distribution of the proportion of bacteriocytes (BC) (a), mucocytes (MC) (b), the ciliated zone (CZ) (c) and lacunal/interfilamentar space (LIS) (d) in the gill tissue. The data was obtained by pooling the values from all individuals (small, medium, large) and all gill regions (Ant, Med, Post) from all sampling dates. The mean value is indicated by a black 
arrow. The number above the bars corresponds to the exact number of values in that proportional range.

In approximately $85 \%$ of the gill tissue samples, the proportion of bacteriocytes fluctuated between $40 \%$ and $70 \%$ (Fig. 3a). With a moderate $\mathrm{CV}$ value $(\mathrm{CV}=20 \%)$, bacteriocytes represented a major and constant component in Loripes gills. The most variable gill component was mucocytes. The mean proportion of mucocytes was $7.6 \pm 12.6 \%$ of gill tissue, but this masked significant variability $(\mathrm{CV}=166 \%)$. Fig. $3 \mathrm{~b}$ shows that approximately half the samples (314 out of 647) corresponded to individuals without mucocytes. Thus mucocytes can be considered optional in the gill tissue of Loripes. For individuals with mucocytes, $41 \%$ had a proportion lower than $20 \%$. A few individuals showed an extremely high proportion of mucocytes compared to the mean value, sometimes reaching $80 \%$ of the gill tissue. As an illustration, the photo in Fig. 2c represents a gill with $70 \%$ mucocytes. The second largest constant component was the ciliated zone, which accounted for $26.2 \pm 5 \%$ of the gill tissue, with limited variation $(\mathrm{CV}=19 \%)$ (Fig. 3c). The lacunal/interfilamentar space represented $9.8 \pm 8.5 \%$ (mean value) of the gill tissue, with significant variability $(\mathrm{CV}=88 \%)$. This space was not a constant component of the gill, as around $10 \%$ of the values were equal to 0 . Around $80 \%$ of the values relative to the lacunal/interfilamentar space present in the gill were in low proportions $(<20 \%$ of the gill tissue).

\section{Seasonal influence on gill tissue composition}

Over the sampling period, the data clearly showed that the average proportion of bacteriocytes changed over time, ranging from $48 \pm 17.2 \%$ to $62.2 \pm 11.3 \%$ (Fig. $4 a$ ). 
a

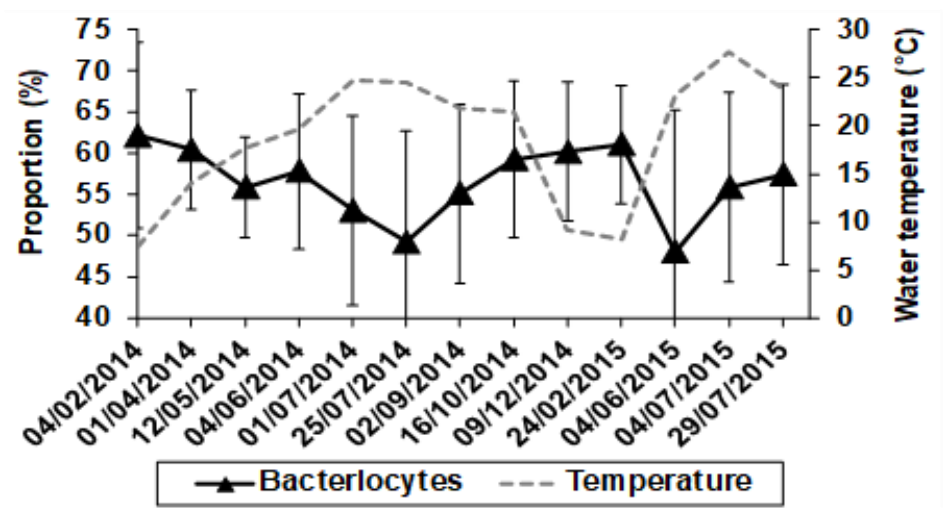

b

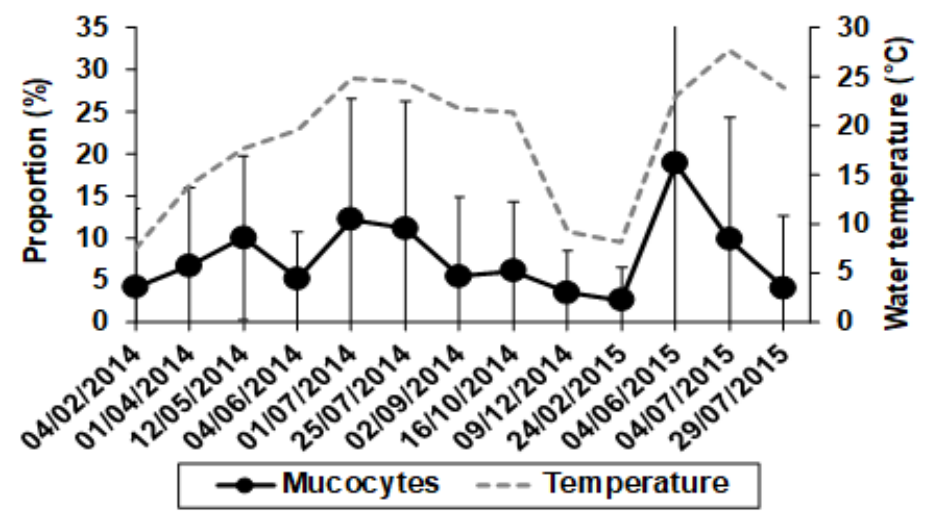

C
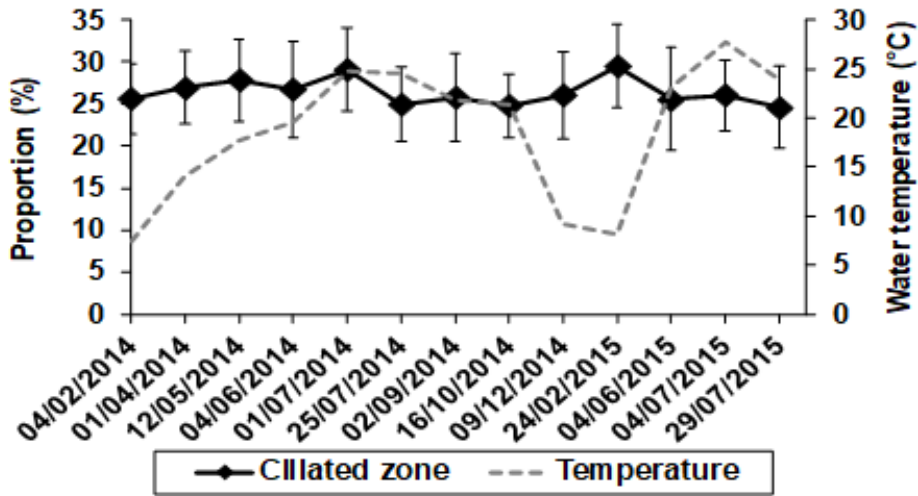

d

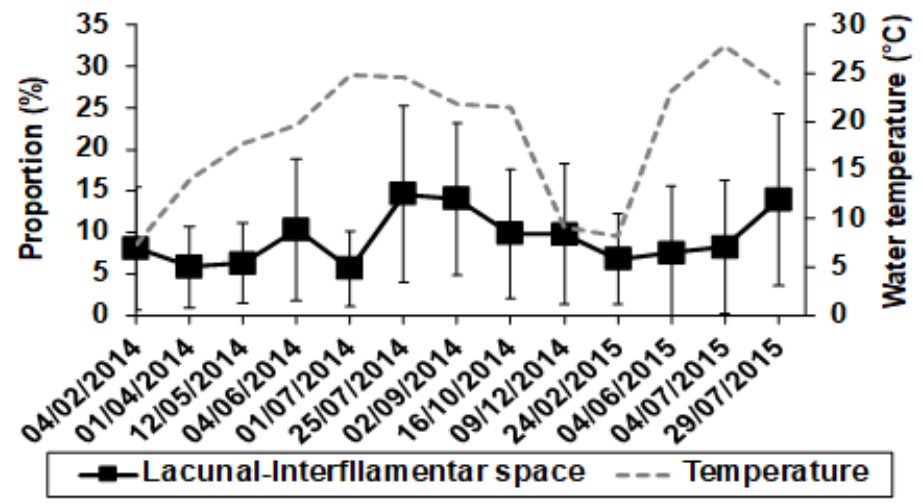

Fig. 4 Change over time (from February 2014 to July 2015) in the proportion (\%) of gill components: bacteriocytes (a), mucocytes (b), ciliated zone (c) and lacunal/interfilamentar space (d) in Loripes gills. Standard deviations are represented by vertical bars; for large standard deviation ranges, the lower bar could not be fully represented. 
310 The highest values were observed in winter, whereas the lowest were observed during warm periods (end of July 2014 and beginning of June 2015). The proportion of bacteriocytes in the gill tissue was noticeably reduced as water temperature increased. Non-parametric tests

313 (Spearman's correlation) confirmed that the proportion of bacteriocytes was significantly and 314 negatively correlated with water temperature $(r s=-0.835, P=0.001)$ and with salinity ( $r s$ $315=-0.687, P=0.012)$.

316 Conversely, the proportion of mucocytes seemed to follow the trend in variation in water temperature (Fig. 4b). Maximum values occurred at the beginning and end of July 2014 (11.2 $\pm 15.2 \%$ and $12.2 \pm 14.3 \%)$ and at the beginning of June $2015(18.8 \pm 25.4 \%)$ when water reached its maximum temperature (between $23.1^{\circ} \mathrm{C}$ and $24.8^{\circ} \mathrm{C}$ ). Spearman's correlation tests showed that mucocytes were significantly and positively related with water temperature ( $r s=0.621, P=0.026$ ), indicating that they appeared in the gill during warm periods. Moreover, the data showed that bacteriocytes and mucocytes were significantly and negatively correlated $(r s=-0.808, P=0.0001)$, indicating that mucocytes appear in the gills along with a simultaneous reduction in bacteriocytes. The proportions of the ciliated zone and the lacunal/interfilamentar space did not show any correlation with temperature or indicate any specific trend according to season.

\section{Biological influence on gill tissue composition}

Among the biological factors that may influence the proportions of the different gill components, we investigated the anterior, median and posterior regions of the gill, and the size and sex of individuals.

\section{Influence of gill region}

333 Along the anteroposterior axis, all data considered and independently of season, the general trend showed a significant increase in the mean proportion of bacteriocytes from the anterior to the posterior region (ESM, Fig. S2a), while the proportion of mucocytes significantly decreased (ESM, Fig. S2b), according to the Kruskal-Wallis test. Considering both the gill region and the season, the results showed that the lowest proportion of bacteriocytes occurred in the anterior part of the gills (44\% in July 2014 and 42.3\% in June 2015) when the water temperature reached between $20^{\circ} \mathrm{C}$ and $25^{\circ} \mathrm{C}$ (Fig. 5a). In contrast, at the same periods, the 
340 highest proportion of mucocytes (21.8\% and 23.1\%) occurred in the anterior region (during 341 early summer 2014 and late spring 2015 respectively) (Fig. 5b). Thus the influence of warm 342 temperatures on gill composition seen in Fig.4 is even more pronounced in the anterior part of 343 the gill. In contrast, the proportion of the ciliated zone remained constant throughout the 344 antero-posterior axis of the gill ( $\approx 26 \%$ ) (ESM, Fig. S2b), and the proportion of the 345 lacunal/interfilamentar space was found to be significantly higher in the median region of the 346 gill (12.1 $\pm 9.1 \%)$ (ESM, Fig. S2b), but was not correlated with water temperature, as stated 347 previously (Fig. 4d). 


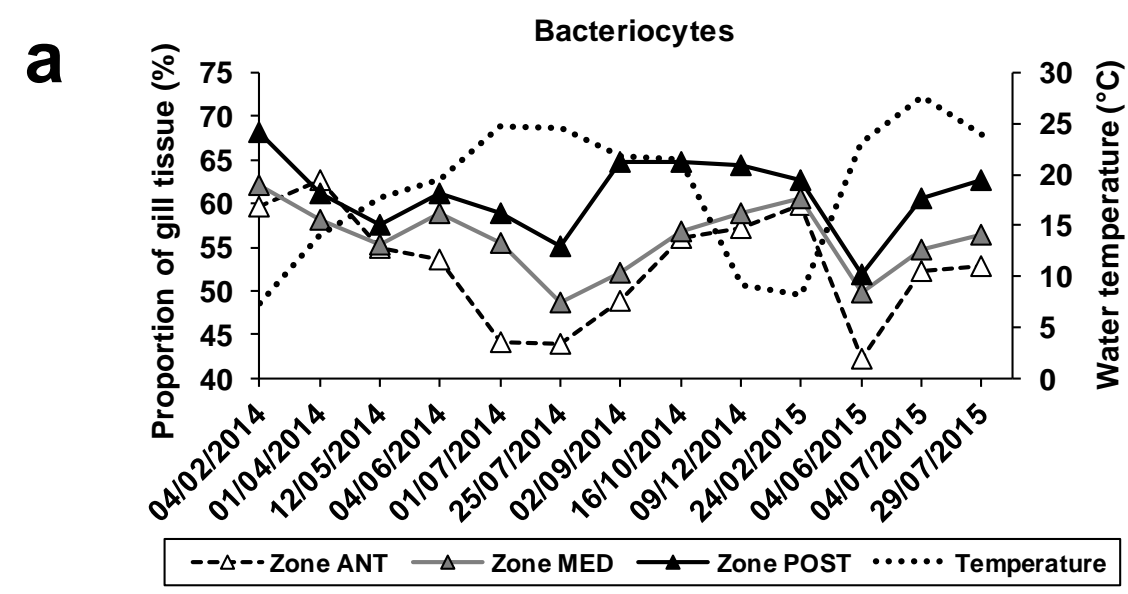

b

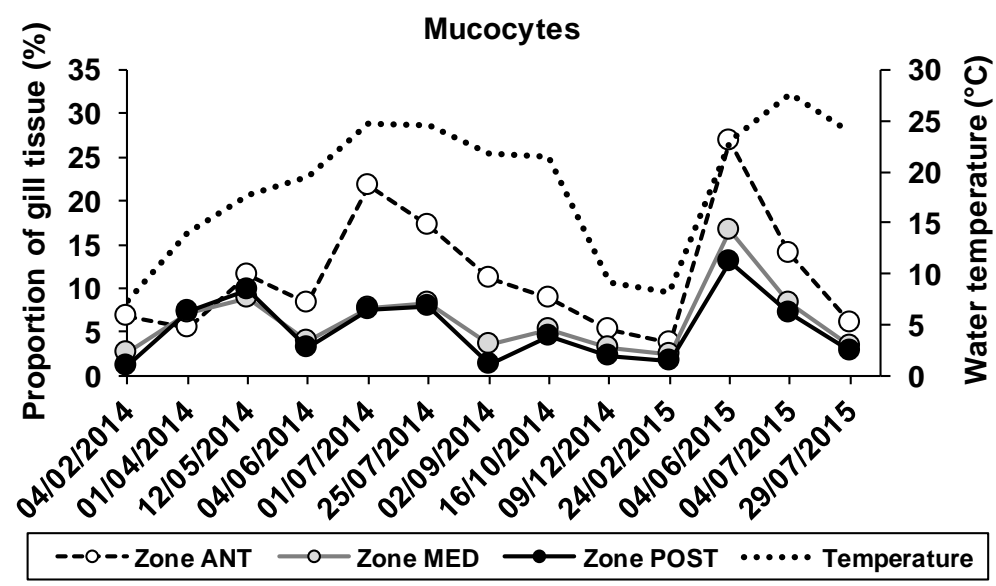

C $\cong$

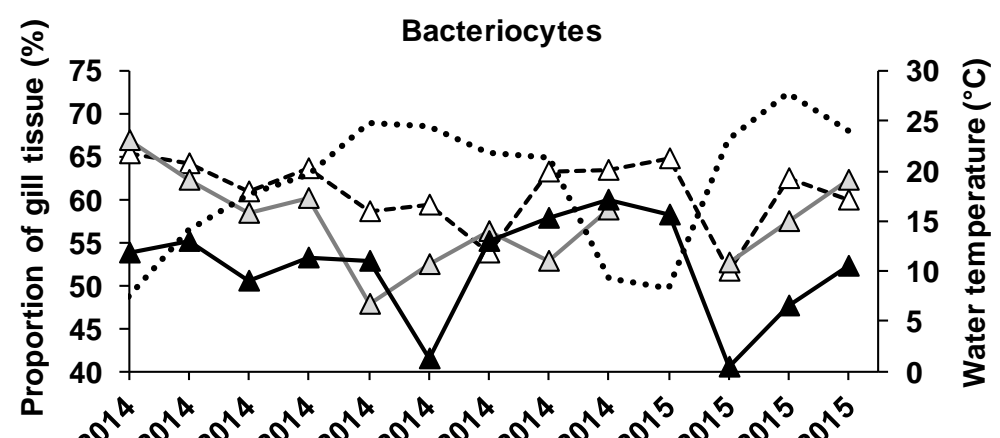

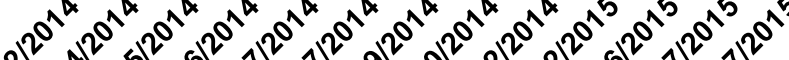

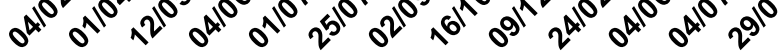

$--\Delta--$ Small $\triangle$ - Medium $\multimap$ Large $\cdots \cdot \cdot$... Temperature

d

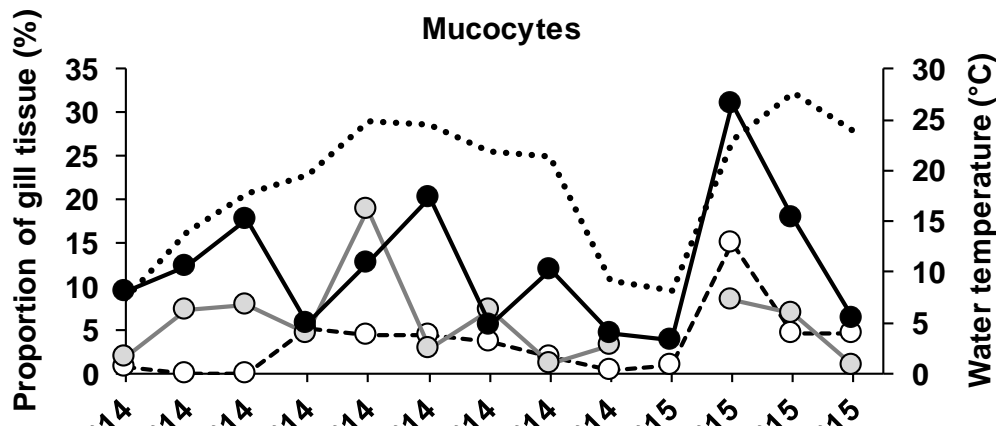

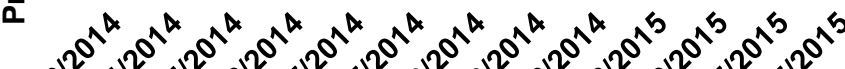

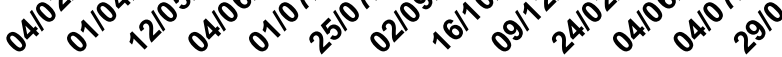

$--0--$ Small $-0-$ Medium $\rightarrow-$ Large $\cdots . . .$. Temperature 
350 Fig. 5 Change over time (from February 2014 to July 2015) of proportions (\%) of 351 bacteriocytes (a and $\mathbf{c}$ ) and mucocytes (b and $\mathbf{d}$ ) in different gill regions (Zones ANT, MED, POST) (a and b) and in different size classes of individual (Small, Medium, Large) (c and d). Water temperature is represented by the dotted line.

\section{Influence of individual's size}

356

357

All the individuals examined were adults, but they ranged in size. The results showed that independently of season, the proportion of bacteriocytes decreased significantly between small $(60.9 \pm 9.5 \%)$ and large individuals $(52.6 \pm 11.9 \%)$ (ESM, Fig. S2c). This was also confirmed through the temporal variation in bacteriocytes, with the greatest decrease occurring in large individuals in late spring (41.4\%) to early summer (40.6\%) (Fig. 5c). An opposite trend was observed for the proportion of mucocytes, which increased significantly between small $(3.8 \pm 10.3 \%)$ and large $(11.4 \pm 14 \%)$ individuals (ESM, Fig. S2d). In terms of temporal variation, the largest proportions of mucocytes were observed during late spring $(31.1 \%)$ to early summer $(20.2 \%)$ in large individuals (Fig. 5d). Without considering season, the highest proportion of the mean ciliated zone and the lowest proportion of lacunal/interfilamentar space were found in small individuals (ESM, Fig. S2d).

\section{Influence of sex/reproductive status}

We also investigated gill tissue composition in relation to the reproductive status of individuals; all data considered independently of season, no statistical differences were found between females and males for any gill tissue components (ESM, Fig. S2e, S2f). Interestingly, compared to sexually determined individuals, sexually undetermined individuals showed a significantly higher proportion of bacteriocytes and a much lower proportion of mucocytes. As this could suggest a possible relationship between the balance of mucocytes/bacteriocytes and the reproductive cycle, we investigated the temporal variation, throughout the studied period, in the percentage of sexually determined individuals (pooling together females and males) and the percentage of mucocytes (Fig. 6). We found that variation in the proportion of mucocytes followed, with a short delay, the trend of the reproductive cycle. 


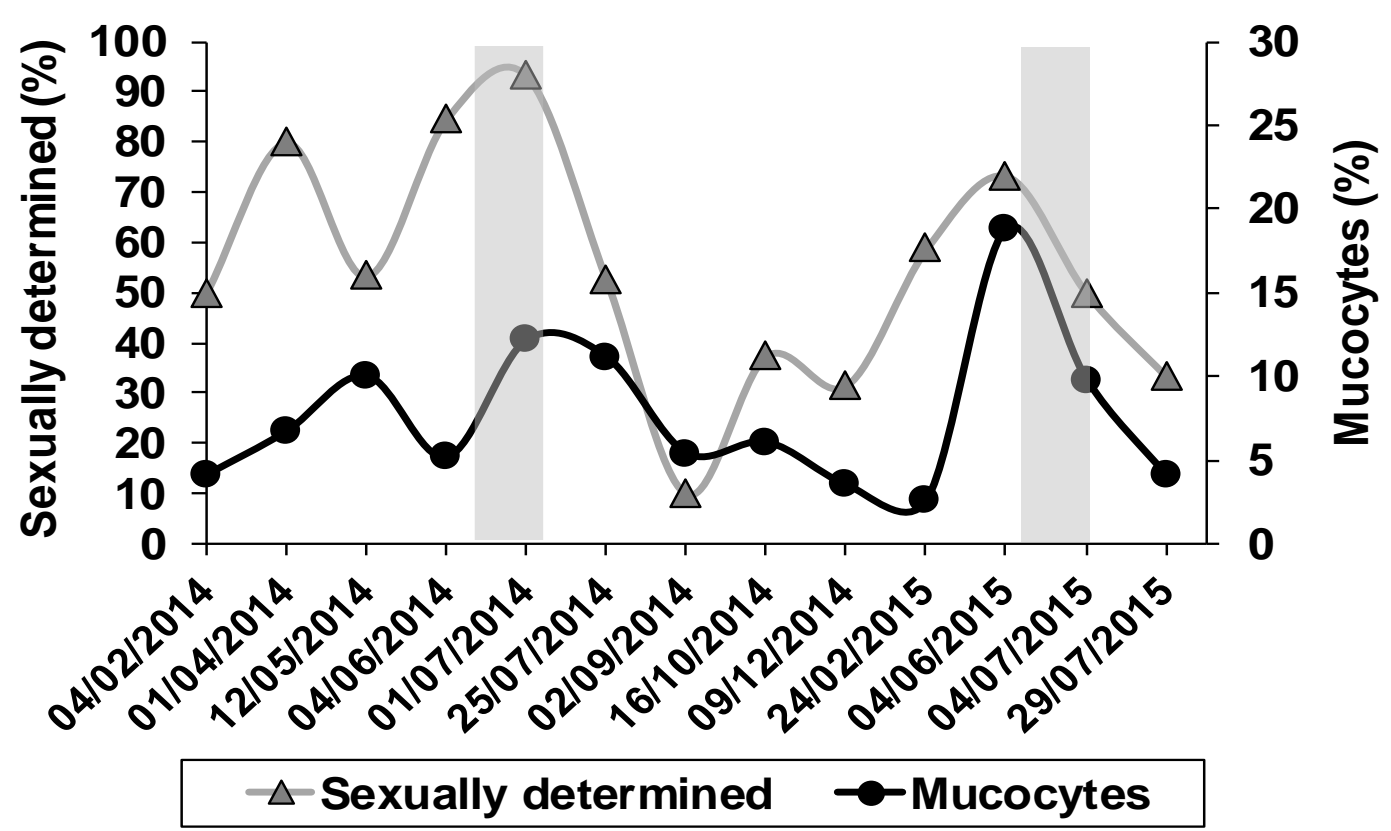

Fig. 6 Change over time (from February 2014 to July 2015) in the percentage of sexually determined individuals and mucocytes. Grey areas correspond to estimated spawning periods according to personal observations of egg masses in the field in 2017 and 2018 at the Bouzigues site.

Spearman's correlation tests were performed on this data, demonstrating, by shifting mucocyte data one month earlier, a positive correlation between sexually determined individuals and mucocytes $(r s=0.764, P=0.006)$. This indicates that the occurrence of mucocytes and the reproductive cycle are related.

\section{Discussion}

In this large field survey of a seagrass meadow in Thau lagoon near Bouzigues, we found a very stable, high density Loripes population throughout the year (mean of 3395 individuals m $^{-}$ ${ }^{2}$ ). A recent study revealed, however, that this density is spatially variable within Thau lagoon and is correlated with seagrass density and organic matter in the sediment (van der Geest et al. 2020). In comparison, much lower Loripes density has been observed in Corsica (777 Loripes $\mathrm{m}^{-2}$ ) (Johnson et al. 2002) and in Mauritania (320-838 Loripes $\mathrm{m}^{-2}$ ); (Ahmedou Salem et al. 2014). In our study, one major reproductive period was identified during late spring/early summer, with spawning estimated to occur in June/July, which is consistent with other areas (Brittany in France and Mauritania) (Johnson and Le Pennec 1994; Johnson and Fernandez 2001; van der Geest et al. 2014). 
Aside from the reproductive cycle, we also investigated seasonal variation in gill tissue composition. The results showed that bacteriocytes are a key component of gill tissue (mean value of $56.4 \%$, with values ranging from $40-70 \%$ ) and are always present, whatever the season, the size or the sex of adult Loripes. This is in line with the value (55\%) reported in other studies (Herry et al. 1989; Johnson and Fernandez 2001; Pales-Espinosa et al. 2013b), supporting the idea that symbionts are the main contributor (between $60 \%$ and $75 \%$ ) to host nutrition in lucinid clams via autotrophic pathways (Johnson et al. 1994; Rossi et al. 2013).

As our study examined a very large number of individuals, it also brings new insights about the discrete occurrence of mucocytes at the population level. We found that mucocytes were only present in half the individuals, in low proportions (mean value $7.6 \%$ ), but with a large range of variation between individuals. These results indicate that mucocytes can be considered an optional and highly variable component of Loripes gill tissue, explaining why they are mentioned as rare cells in the literature on Loripes and more generally in lucinids (Herry et al. 1989; Liberge et al. 2001; review in Duplessis et al. 2004; Pales-Espinosa et al. 2013b). In comparison, the gill tissue of other lucinids (e.g. Codakia sp.) contains bacteriocytes, but in lower proportion (30\%), some rare mucocytes, and granular cells absent from Loripes gills (Caro et al. 2009; Gros et al. 2012). Mucocytes are also mentioned in some Thyasiridae bivalves, but without precise quantification (Dufour 2006). This gill tissue variability in symbiotic bivalves probably corresponds to differences in host physiology and modes of nutrition, potentially related to the environment. In future studies, it would be useful to consider the gills of Loripes, and other symbiotic species more generally, not as composed strictly of bacteriocytes, but as dynamic tissue with varying proportions of bacteriocytes and mucocytes and potentially other cells.

Our findings also demonstrated a seasonal pattern in the dynamic of mucocytes and bacteriocytes, with larger proportions of mucocytes in late spring/early summer (as water reaches its maximum temperature). In Thau lagoon at this period, the main primary production bloom occurs (Bec et al. 2005), and a possible hypothesis is that mucocytes may be involved in the heterotrophic nutrition of the host as is the case for other bivalves; one of the main roles attributed to the mucus secreted by mucocytes concerns particle-feeding processes (Beninger and St Jean 1997). Another hypothesis concerns host immunity, as gills and mucus are greatly involved in this function (Allam and Pales-Espinosa 2016; Yuen et al. 2019). Moreover, since 2008, massive spring mortality has been regularly recorded in oysters 
in the Thau lagoon (Pernet et al. 2012), involving a community of pathogenic microorganisms (Alfaro et al. 2019) that may trigger Loripes' defence systems.

Several arguments may support the first hypothesis that mucocytes could be involved in particle processing. Indeed, Loripes orbiculatus is generally attributed a mixotrophic status, with a significant part of chemoautotrophic nutrition (Schweimanns and Felbeck 1985; Herry et al. 1989; Taylor and Glover 2006), but supplemented by heterotrophic feeding through the ingestion of particulate organic matter (Le Pennec et al. 1988; Duplessis et al. 2004; Rossi et al. 2013; van der Geest et al. 2014). A similar temporal fluctuation in symbiont abundance, a proxy for bacteriocytes, was also observed in Thysirids according to season (Laurich et al. 2015). More recently, the postulate of the heterotrophic nutrition of Loripes has been strengthened by the ability of this host's symbionts to digest complex polysaccharides (Yuen et al. 2019), typically found in marine phytoplankton (Mühlenbruch et al. 2018). In suspension-feeding bivalves, heterotrophic nutrition is related to the ability of the gills to collect and process particulate organic matter via mucocytes' acid secretion from the anterior part of the gill (Beninger and Dufour 1996; Beninger and St Jean 1997; Ward and Shumway 2004). Our data demonstrated a larger proportion of acid mucocytes (from PAS-AB staining) in the anterior region of the gill, which Beninger et al. (2003) considers, given the type and location, to be mucocytes obviously involved in particle capture. According to REPHY data (2018), a spring phytoplankton bloom occurred in 2014 and 2015 at the Bouzigues site, dominated both years by large diatom species (mainly Chaetoceros), as well as some smaller benthic diatoms such as Navicula. As the increase in mucocytes observed in our study coincided with these blooms, we cannot exclude the possibility that mucocytes could occur in Loripes gills in order to benefit from this particulate nutrition source, after it sinks to the sediment below (Souchu et al. 1998). Indeed, particulate food is known to be energetically more valuable for symbiotic bivalves than chemoautotrophic nutrition (Le Pennec and Beninger 2000). Small epiphytic diatoms $(20 \mu \mathrm{m})$, which cover the leaves of Zostera noltii, as has been described in intertidal zones (Lebreton et al. 2009), could be another potential particulate food source for Loripes, as diatoms have been found in the digestive system of lucinids, among other organic particles (Le Pennec et al. 1988; Dando et al. 1986; Southward 1986; Herry and Le Pennec 1987; Duplessis et al. 2004). The high nutritional quality of benthic diatoms, and microphytobenthos more generally, sustain the growth of non-symbiotic benthic bivalves (Lebreton et al. 2011) and could also be part of the heterotrophic nutrition of symbiotic species such as Loripes, considered a filter- and deposit-feeder. The low biomass 
represented by microphytobenthos in Z. noltii seagrass beds (Lebreton et al. 2009) could still be sufficient to fuel the supplemental heterotrophic nutrition of Loripes, as autotrophic nutrition represents only 60-75\% of host nutrition in lucinids (Cary et al. 1989).

Concerning the potential involvement of mucocytes in Loripes immunity, our field survey was not designed to investigate this question, so we can only speculate on this point. The diseases that regularly affect oyster spats in Thau lagoon when the water temperature rises to $16-17^{\circ} \mathrm{C}$ in spring include the herpes virus OsHV-1 $\mu$ var and a Vibrio community (see review in Destoumieux-Garzon et al. 2020). Non-symbiotic benthic bivalves (e.g. the Ruditapes clam, Cerastoderma cockle, Haliotis abalone, Chlamys scallop, etc.) are also affected by harmful bacteria and viruses (Renault et al. 2001; Paillard et al. 2006; Arzul et al. 2017), but as most studies to date have focused on farmed bivalves (Travers et al. 2015), as far as we are aware, information is scarce about pathogenic agents that could infect Loripes (Johnson and Le Pennec 1995). Nevertheless, the sediment in Thau lagoon is assumed to be a reservoir of Vibrio species that are pathogenic for oysters during winter and, to a lesser extent, during spring (Lopez-Joven et al. 2018). Even trapped in the sediment, these Vibrio species may also trigger an immune response in Loripes through the appearance of mucocytes in the gills and mucus secretion, yet without causing significant mortality, since our data found Loripes density to be stable over the years. The gene expressions involved in immunity response to bacteria has indeed been recently evidenced in the transcriptome of the Loripes gill (Yuen et al. 2019). Further studies could aim to correlate transcriptomic and histological data in order to clarify the role of mucocytes.

Our findings also highlighted that mucocytes mainly occur in large adults, and that their proportion is positively correlated with water temperature and with the sexual maturation of Loripes. This suggests that the factors underlying mucocyte emergence are related to metabolic demands in line with gonadal maturation in adults able to reproduce. Johnson and Fernandez (2001) noted a correlation between gametogenesis and symbiont lysis inside bacteriocytes in Loripes; they suggested that the supplemental energy demands related to gametogenesis could be sustained by 'heterosynthetic metabolites'. Indeed, high-nutrition food is required to ensure gonadal development in molluscs (Bayne and Newell 1983; Hilbish and Zimmerman 1988), as well as favourable temperatures (Morgan et al. 2013). The diet of other non-symbiotic benthic bivalves also varies according to the biological stage of the species (from juvenile to adult) (Kang et al. 1999), possibly related to reproduction, and according to the seasonal availability of microphytobenthos as a heterotrophic source of 
nutrition (Kang et al. 2006). The beneficial effect of heterotrophic nutrition to ensure gonadal maturation is also valuable for other invertebrates such as corals (Séré et al. 2010). If Loripes mucocytes effectively contribute to particle nutrition, that would suggest that the small adults in our study rely more on autotrophic nutrition and then shift to a higher amount of heterotrophic nutrition, as seen in larger adults, to sustain reproduction during spring. This hypothesis is in line with recent $\mathrm{C}$ and $\mathrm{N}$ stable isotope ratio findings on Loripes, which show an increasing level of autotrophy from April to October (Cardini et al. 2019). These authors suggest that host nutrition relies on heterotrophy during spring and then turns mainly to chemoautotrophic nutrition during autumn. Similar variations in the C and N stable isotope ratios between seasons were also reported in the same species by Carlier et al. (2007) in the south of France (Lapalm lagoon) and in Mauritania (van der Geest et al. 2014). Unfortunately, during our survey we did not measure phytoplankton in the water column, or particulate organic carbon or sulphide levels in the sediment, so we could not correlate the proportion of bacteriocytes versus mucocytes to these parameters. However, the sulphide level measured in Thau lagoon during the summer of 2016 remained close to zero (van der Geest et al. 2020), whereas organic matter is in theory high in late spring/early summer at the sediment surface (Rossi and Gili 2007; Lebreton at al. 2009). This is in line with the generally low values of sulphide found in lucinid habitats (Cary et al. 1989).

Based on the previous arguments, we posit that mucocytes, given their correlation with water temperature and the size and reproductive status of the host, contribute to the host's heterotrophic nutrition, without ruling out a potential role in host immunity. Isotopic ratio and transcriptomic data (Carlier et al. 2007; van der Geest at al., 2014; Cardini et al. 2019; Yuen et al. 2019) helped both to throw light on these findings and confirm them. The balance between bacteriocytes and mucocytes, varying seasonally to sustain reproduction, give histological support for the well-known mixotrophic status of Loripes, which shifts from autotrophy to heterotrophy. The low proportion of mucocytes in Loripes gill composition found in our study might be sufficient to supplement the host's autotrophic nutrition (60$75 \%$ ) with heterotrophic nutrition. A mixotrophic diet might represent a strategy for symbiotic bivalves living in shallow water environments to benefit from variable nutrient resources (sulphides, particulate organic matter, etc.). For other filter- and deposit-feeders such as Cnidarians, Sponges, Ascidians, and some bivalve Molluscs, another strategy, called the 'dormant state', is adopted to cope with the variability in composition and availability of 
particulate organic matter at the sediment surface during spring and summer (Ribes et al. 1999; Coma and Ribes 2003).

By extrapolating our results throughout the lifetime of a Loripes bivalve, we suggest that before being able to reproduce, this species relies on the symbionts hosted in bacteriocytes for its nutrition by 'milking' (direct carbon transfer) (Schweimanns and Felbeck 1985; Herry et al. 1989; Yuen et al. 2019) and 'farming' (host digestion of the symbionts), as has been described for other lucinids (Caro et al. 2009; Elisabeth et al. 2014; König et al. 2015). Then, when sexual maturation occurs in larger individuals, we posit that this triggers an annual cycle of histological gill variation in relation to gametogenesis (summarized in ESM, Fig. S3). During spring, a regression in bacteriocytes occurs along with the appearance of mucocytes, to allow particle feeding during phytoplankton blooms, in order to sustain the metabolic demands related with reproduction through heterotrophy. Then immediately after spawning in June/July, host nutrition rapidly returns to a standard symbiotic and autotrophic metabolism from July to February, with a dominance of bacteriocytes in the gill tissue (ESM, Fig. S3). This flexible metabolism is of particular importance in the context of global warming, with its potential increase in the frequency of extreme environmental conditions.

\section{Conclusion}

In this field survey, we quantified the occurrence of mucocytes and their trade-off with bacteriocytes in the gill tissue of the lucinid species Loripes orbiculatus. Mucocytes occur in low proportions in the gill tissue, except during spring in large adults. Our findings could allow new insights into the biological and environmental drivers underlying this gill plasticity. The reproductive cycle was identified as the main biological factor triggering mucocyte appearance, coinciding with the period when primary production is high. This is the first field study providing histological support to describe the biological traits and environmental conditions underlying the 'mixotrophic diet' of this species - and potentially that of other lucinids. The high variability in histological gill composition between individuals and according to season could perhaps explain the variability of stable isotope measurements (Cardini et al. 2019; van der Geest et al. 2014, 2020). In future studies of lucinids and other symbiotic species, a large sample of individuals of the same size would be valuable. To further investigate the role of mucocytes, transcriptomic investigations could be conducted on individuals with and without mucocytes to compare their profiles. The microbiome of gill tissue could also be investigated in small versus large individuals, as gill-secreted mucus may 
trap and host heterotrophic bacteria from the environment that could contribute to the heterotrophic nutrition of the host as part of its 'holobiont'.

\section{Compliance with ethical standards}

568 Conflicts of interest All authors declare that they have no conflicts of interests.

569 Ethical approval All applicable international, national, and/or institutional guidelines for the 570 care and use of animals were followed.

571 Funding There was no external funding.

Acknowledgements This study was partially funded by the Coastal Marine Ecosystems research unit (ECOSYM) (recurring annual grant) and the Marine Biodiversity Exploitation and Conservation research unit (MARBEC). We would like to thank the MARBEC Microbex and histological platforms for their technical support, the Montpellier Ressources Imagerie MRI platform for image analysis, Elise Bradbury for the editorial review of the manuscript, and Matthijs van der Geest for his useful input during discussions.

Author contributions This study was designed by AC, CR; the field work was carried out by AC and CR; CR, EG, SH, JLC and AC collected the data; CR and CS contributed to the software development; MT analysed the data; AC, CR, MT and JLC wrote the manuscript. All authors read and approved the final manuscript.

Data availability The datasets collected and analysed during the study are available from the corresponding author. 


\section{References}

Ahmedou Salem MV, van der Geest M, Piersma T, Saoud Y, van Gils JA (2014) Seasonal changes in mollusc abundance in a tropical intertidal ecosystem, Banc d'Arguin (Mauritania) : testing the 'shorebird depletion' hypothesis. Estuar Coast Shelf Sci 136:2634. https://doi:10.1016/j.ecss.2013.11.009

Alfaro AC, Nguyen TV, Merien F (2019) The complex interactions of Ostreid herpesvirus 1, Vibrio bacteria, environment and host factors in mass mortality outbreaks of Crassostrea gigas. Rev Aquac 11:1148-1168. https://doi:10.1111/raq.12284

Allam B, Pales-Espinosa E (2016) Bivalve immunity and response to infections : are we looking at the right place ? Fish Shellfish Immunology 53:4-12. http://dx.doi.org/10.1016/j.fsi.2016.03.037

Allam B, Raftos D (2015) Immune responses to infectious diseases in bivalves. J Invertebrates Pathology 131:121-136. http://dx.doi.org/10.1016/j.jip.2015.05.005

Allen JA (1958) On the basic form and adaptations to habitat in the Lucinacea (Eulamellibranchia). Phil Trans R Soc (Ser B) 241:421-484. https://doi.org/10.1098/rstb.1958.0010

Arzul I, Corbeil S, Morga B, Renault T (2017) Viruses infecting marine molluscs. J Invert Pathol 147:118-135. https://doi:10:1016/j.jip.2017.01.009

Bayne BL, Newell RC (1983) Physiological energetics of marine molluscs. In: The Mollusca, (ed A.S.M. Saleuddin and K.M. Wilbur), pp.407-515. New York: Academic Press.

Bec B, Husseini-Ratrema J, Collos Y, Souchu P, Vaquer A (2005) Phytoplankton seasonal dynamics in a Mediterranean coastal lagoon: emphasis on the picoeukaryote community. $\mathbf{J}$ Plankton Res 27:881-894. https://doi .org/10.1093/plankt/fbi061

Beninger PG, St-Jean SD, Poussart Y, Ward JE (1993) Gill function and mucocyte distribution in Placopecten magellanicus and Mytilus edulis (Mollusca: Bivalvia): the role of mucus in particle transport. Mar Ecol Prog Ser 98:275-282.

Beninger PG, Dufour SC (1996) Mucocyte distribution and relationship to particle transport on the pseudolamellibranch gill of Crassostrea virginica (Bivalvia: Ostreidae). Mar Ecol Prog Ser 137:133-138. https://doi:10.3354/meps137133

Beninger PG, Dufour SC, Bourque J (1997) Particle processing mechanisms of the eulamellibranch bivalves Spisula solidissima and Mya arenaria. Mar Ecol Prog Ser 150: 157-169. https://doi:10.3354/meps150157 
Beninger PG, St-Jean SD (1997) The role of mucus in particle processing by suspensionfeeding marine bivalves: unifying principles. Mar Biol 129:389-397. https://doi.org/10.1007/s002270050179

Beninger PG, Dufour SC, Decottignies P, Le Pennec M (2003) Particle processing mechanisms in the archaic, peri-hydrothermal vent bivalve Bathypecten vulcani, inferred from cilia and mucocyte distributions on the gill. Mar Ecol Prog Ser 246:183195. https:// doi:10.3354/meps 24618

Cardini U, Bartoli M, Lücker S, Mooshammer M, Polzin J, Lee RW, Micić V, Hofmann T, Weber M, Petersen J (2019) Chemosymbiotic bivalves contribute to the nitrogen budget of seagrass ecosystems. ISME Journal 13:3131-3134. https://doi.org/10.1038/s41396-0190486-9

Carlier A, Riera P, Amouroux JM, Bodiou, JY, Escoubeyrou K, Desmalades M, Caparros J, Grémare A (2007) A seasonal survey of the food web in the Lapalme Lagoon (northwestern Mediterranean) assessed by carbon and nitrogen stable isotope analysis. Estuar Coast Shelf Sci 73:299-315. https://doi:10.1016/j.ecss.2007.01.012

Caro A, Got P, Bouvy M, Troussellier M, Gros O (2009) Long term feeding starvation of host bivalve (Codakia orbicularis, Lucinidae) and effects on its symbiont population. Applied Environmental Microbiology 75 (10):3304-3313. https://doi.org/ 10.1128/AEM.02659-08

Cary SC, Vetter RD, Felbeck H (1989) Habitat characterization and nutritional strategies of the endosymbiont-bearing bivalve, Lucinoma aequizonata. Mar Ecol Prog Ser 55:31-45. https://dx.doi.org/10.3354/meps055031

Coma R, Ribes M (2003) Seasonal energetic constraints in Mediterranean benthic suspension feeders: effects at different levels of ecological organization. OIKOS 101:205-215

Dando PR, Southward AJ, Southward EC (1986) Chemoautotrophic symbionts in the gills of the bivalve mollusc Lucinoma borealis and the sediment chemistry of its habitat. Proceedings Royal Society London B. 227:227-247.

Dando PR, Spiro B (1993) Varying nutritional dependence of the thyasirid bivalves Thyasira sarsi and T. equalis on chemoautotrophic symbiotic bacteria, demonstrated by the isotope ratios of tissue carbon and shell carbonate. Mar Ecol Prog Ser 92:151-158. https://www.jstor.org/stable/24832625

Destoumieux-Garzon D, Rosa R, Schmitt P, Barreto C, Vidal-Dupiol J, Mitta G, Gueguen Y, Bachère E (2016) Antimicrobial peptides in marine invertebrates health and disease. https://doi.org/10.1098/rstb.2015.0300 
Destoumieux-Garzon D, Canesi L, Oyanedel D, Travers M-A, Charrière G, Pruzzo C, Vezzulli L (2020) Vibrio-bivalve interactions in health and disease. Environ Microbiol https://doi:10.1111/1462-2920.15055

Distel DL, Felbeck H (1987) Endosymbiosis in the lucinid clams Lucinoma aequizonata, Lucinoma annulata and Lucina floridana: a reexamination of the functional morphology of the gills as bacteria-bearing organs. Mar Biol 96:79-86. https://doi: 10.1007/BF00394840

Dufour S, Beninger P (2001) A functional interpretation of cilia and mucocyte distributions on the abfrontal surface of bivalve gills. Mar Biol 138:295-309. https://doi.org/10.1007/s002270000466

Dufour S (2005) Gill anatomy and the evolution of symbiosis in the bivalve family Thyasiridae. Bio Bull 208(3):200-212. https://doi: 10.2307/3593152

Duplessis MR, Dufour SC, Blankenship LE, Felbeck H, Yayanos AA (2004) Anatomical and experimental evidence for particulate feeding in Lucinoma aequizonata and Parvilucina tenuisculpta (Bivalvia: Lucinidae) from the Santa Barbara Basin. Mar Biol 145:551-561. https://dx.doi.org/10.1007/s00227-004-1350-6

Elisabeth N, Caro A, Césaire T, Mansot J-L, Escalas A, Sylvestre M-N, Jean-Louis P, Gros O (2014) Comparative modifications in bacterial gill-endosymbiotic populations of the two bivalves Codakia orbiculata and Lucina pensylvanica during bacterial loss and reacquisition. FEMS Microbiol Ecol 89:646-658. https://doi.org/10.1111/15746941.12366

Felbeck H, Childress J, Somero G (1981) Calvin-Benson cycle and sulphide oxidation enzymes in animals from sulphide-rich habitats. Nature, London 293:291-293.

Gabe M (1968) Techniques histologiques. Masson, Paris.

Gourdine J-P, Smith-Ravin EJ (2007) Analysis of a cDNA-derived Sequence of a Novel Mannose-Binding Lectin, Codakine, From the Tropical Clam Codakia orbicularis. Fish Shellfish Immunol. 22(5):498-509. https://doi:10.1016/j.fsi.2006.06.013

Gros O, Elisabeth N, DD Gustave S, Caro A, Dubilier N (2012) Plasticity of symbiont acquisition throughout the life cycle of the shallow-water tropical lucinid Codakia orbiculata (Mollusca: Bivalvia). Environ Microbiol 14(6):1584-1595. https://doi:10.1111/j.1462-2920.2012.02748.x

Herry A, Le Pennec M (1987) Endosymbiotic bacteria in the gills of the littoral bivalve molluscs Thyasira flexuosa (Thyasiridae) and Lucinella divaricata (Lucinidae). Symbiosis 4:25-36. 
Herry A, Diouris M, Le Pennec M (1989) Chemoautotrophic symbionts and translocation of fixed carbon from bacteria to host tissues in the littoral bivalve Loripes lucinalis (Lucinidae). Mar Biol 101:305-312. https://doi.org/10.1007/BF00428126

Hilbish TJ, Zimmerman KM (1988) Genetic and nutritional control of the gametogenic cycle in Mytilus edulis. Mar Biol 98: 223-228. https://doi.org/10.1007/BF00391198

Johnson MA, Le Pennec M (1994) The development of the female gamete in the endosymbiontbearing bivalve Loripes lucinalis. J Mar Biol Assoc UK 74:233-242. https://doi.org/10.1017/S0025315400035797

Johnson MA, Le Pennec M (1995) Association between the mollusc bivalve Loripes lucinalis and a Chlamydia like organism, with comments on its pathogenic impact, life cycle and possible mode transmission. Mar Biol 123:523-530.

Johnson MA, Diouris M, Le Pennec, M (1994) Endosymbiotic bacterial contribution in the carbon nutrition of Loripes lucinalis. (Mollusca:Bivalvia). Symbiosis 17:1-13.

Johnson MA, Paulet YM, Donval A, Le Pennec M (1996) Histology, histochemistry and enzyme biochemistry in the digestive system of the endosymbiont-bearing bivalve Loripes lucinalis (Lamarck). J Exp Mar Biol Ecol 197:15-38. https://doi.org/10.1016/00220981(95)00142-5

Johnson M, Fernandez C (2001) Bacterial symbiosis in Loripes lucinalis (Mollusca: Bivalvia) with comments on reproductive strategy. J Mar Biol Assoc UK 81:251-257. hal-00019189.

Johnson MA, Fernandez C, Pergent G (2002) The ecological importance of an invertebrate chemoautotrophic symbiosis to phanerogam seagrass beds. Bull Mar Sci 71 (3):1343-1351.

Kádár E, Davis SA, Lobo-da-Cunha A (2008) Cytoenzymatic investigation of intracellular digestion in the symbiont-bearing hydrothermal bivalve Bathymodiolus azoricus. Mar Biol 153, 995-1004. https://doi: 10.1007/s00227-007-0872-0

Kang C-K, Sauriau PG, Richard P, Blanchard GF (1999) Food sources of the infaunal suspension-feeding bivalve Cerastoderma edule in a muddy sandflat of Marennes-Oléron Bay, as determined by analyses of carbon and nitrogen stable isotopes. Mar Ecol Prog Ser 187:147-158. https://doi:10.3354/meps 187147

Kang C-K, Lee Y-W, Choy EJ, Shin J-K Seo I-S, Hong J-S (2006) Microphytobenthos seasonality determines growth and reproduction in intertidal bivalves. Mar Ecol Prog Ser 315:113-127. https://doi:10.3354/meps315113

König S, Le Guyader H, Gros O (2015) Thioautotrophic bacterial endosymbionts are degraded by enzymatic digestion during starvation: case study of two lucinids Codakia orbicularis and C. orbiculata. MicroscRes Tech 78:173-179. https://doi.org/10.1002/jemt.22458 
König S, Gros O, Heiden S, Hinzke T, Thürmer A, Poehlein A, Meyer S, Vatin M, MbéguiéA-Mbéguié D, Tocny J, Ponnudurai R, Daniel R, Becher D, Schweder T, Markert S (2016) Nitrogen fixation in a chemoautotrophic lucinid symbiosis. Nat Microbiol https://doi:10.1038/nmicrobiol.2016.193

Laurich JR, Batstone RT, Dufour SC (2015) Temporal variation in chemoautotrophic symbiont abundance in the thyasirid bivalve Thyasira cf. gouldi. Mar Biol 162:2017-2028. https://doi:10.1007/s00227-015-2727-4

Lebreton B, Richard P, Radenac G, Bordes M, Bréret M, Arnaud C, Mornet F, Blanchard GF (2009) Are epiphytes a significant component of intertidal Zostera noltii beds? Aquatic Botany 91:82-90. https://doi:10.1016/j.aquabot.2009.03.003

Lebreton B, Richard P, Galois R, Radenac G, Pfléger C, Guillou G, Mornet, F, Blanchard GF (2011) Trophic importance of diatoms in an intertidal Zostera noltii seagrass bed: evidence from stable isotope and fatty acid analyses. Estuar Coast Shelf Sci 92:140-153. https://doi.org/10.1016/j.ecss.2010.12.027

Le Pennec M, Herry A, Diouris M, Moraga D, Donval A (1988) Chimioautotrophie et nutrition chez les Lucinacea, bivalves littoraux de milieux réducteurs. II. Caractéristiques morphologiques des bactéries symbiotiques et modifications anatomiques. Haliotis, Paris $18: 207-217$.

Le Pennec M, Beninger PG (2000) Reproductive characteristics and strategies of reducingsystem bivalves. Comp Biochem Physiol - Part A Mol Integr Physiol 126(1):1-16. https://doi:10.1016/S0742-8413(00)00100-6

Liberge M, Gros O, Frenkiel L (2001) Lysosomes and sulfide-oxidizing bodies in the bacteriocytes of Lucina pectinata, a cytochemical and microanalysis approach. Mar Biol 139:401-409. https://doi.org/10.1007/s002270000526

Lopez-Joven C, Rolland JL, Haffner P, Caro A, Roques C, Carré C, Abadie E, Laabir M, Travers MA, Bonnet D, Destoumieux-Garzon D (2018) Vibrio dynamics in an oyster culture lagoon. A focus on vibrios pathogenic for oysters. Front Microbiol https://doi.org/10.3389/fmicb.2018.02530

Morgan E, O'Riordan RM, Culloty SC (2013) Climate change impacts on potential recruitment in an ecosystem engineer. Ecol Evol 3:581-594. https://dx.doi.org/10.1002/ece3.419

Mühlenbruch M, Grossart H-P, Eigemann F, Voss M (2018) Mini-review: phytoplanktonderived polysaccharides in the marine environment and their interactions with heterotrophic bacteria. Environ Microbiol 20(8):2671-85. https://doi:10.1111/1462$\underline{2920.14302}$ 
Nyholm and McFall-Ngai (2003) Dominance of Vibrio fischeri in secreted mucus outside the light organ of Euprymna scolopes: the first site of symbiont specificity. Appl Envir Microbiol 69(7):3932-3937.

Paillard C, Gausson S, Nicolas J-L, Le Pennec J-P, Haras D (2006) Molecular identification of Vibrio tapetis, the causative agent of the brown ring disease of Ruditapes philippinarum. Aquaculture 253(1-4):25-38. https://doi.org/10.1016/j.aquaculture.2005.03.047

Pales-Espinosa E, Perrigault M, Ward JE, Shumway SE, Allam B (2009) Lectins associated with the feeding organs of the oyster Crassostrea virginica can mediate particle selection. Biol Bull 217:130-141. https://doi: 10.1086/BBLv217n2p130

Pales-Espinosa E, Perrigault M, Allam B (2010a) Identification and molecular characterization of a mucosal lectin (MeML) from the blue mussel Mytilus edulis and its potential role in particle capture. Comp Biochem Physiol - Part A Mol Integr Physiol 156:495-501. https://doi: 10.1016/j.cbpa.2010.04.004

Pales-Espinosa E, Perrigault M, Ward JE, Shumway SE, Allam B (2010b) Microalgal cell surface carbohydrates as recognition sites for particle sorting in suspension-feeding bivalves. Biol Bull 218:75-86. https://doi: 10.1086/BBLv218n1p75

Pales-Espinosa E, Winnicki, S, Allam B (2013a) Early host-pathogen interactions in marine bivalves: pallial mucus of Crassostrea virginica modulates the growth and virulence of its pathogen Perkinsus marinus. Dis Aquat Org 104 (3):327-247

Pales-Espinosa E, Tanguy A, Le Panse S, Lallier F, Allam B, Boutet I (2013b) Endosymbiotic bacteria in the bivalve Loripes lacteus: localization, characterization and aspects of symbiont regulation.

JEMBE 448:327-336. https://dx.doi.org/10.1016/j.jembe.2013.07.015

Pales-Espinosa E, Koller A , Allam B (2016) Proteomic characterization of mucosal secretion in the eastern oyster, Crassostrea virginica. J Proteomics 132:63-76. https://dx.doi.org/10.1016/j.jprot.2015.11018

Pernet F, Mallet N, Pastoureaud A, Vaquer A, Quéré C, Dubroca L (2012) Marine diatoms sustain growth of bivalves in a Mediterranean lagoon. J Sea Res 68:20-32. https://doi: 10.1016/j.seares.2011.11.004

Petersen J, Kemper A, Gruber-Vodicka H, Cardini U, van der Geest M, Kleiner M, Bulgheresi S, Mußmann M, Herbold C, Seah B, Antony C, Liu D, Belitz A, Weber M (2016) Chemosynthetic symbionts of marine invertebrate animals are capable of nitrogen fixation. Nat Microbiol 2, 16195. https//doi:10.1038/nmicrobiol.2016.195 
Reid RGB (1990) Evolutionary implications of sulphide-oxidising symbioses in bivalves. In : The Bivalvia-Proceedings of a memorial symposium in honour of Sir Charles Maurice Yonge, Edinburgh, 1986 (B. Morton Ed.), 127-140. Hong Kong University Press, Hong Kong.

Renault T, Lipart C, Arzul I (2001) A herpes-like virus infecting Crassostrea gigas and Ruditapes philipinarum larvae in France. J Fish Dis 24:369-376.

REPHY - French Observation and Monitoring program for Phytoplankton and Hydrology in coastal waters (2018). REPHY dataset. French Observation and Monitoring program for Phytoplankton and Hydrology in coastal waters. 1987-2018. Metropolitan data. SEANOE. https://doi.org/10.17882/47248\#66472

Reynolds LK, Berg P, Zieman JC (2007) Lucinid clam influence on the biogeochemistry of the seagrass Thalassia testudinum sediments. Estuar Coasts. 30(3):482-490. https://doi.org/10.1007/BF02819394

Ribes M, Coma R, Gili JM (1999) Seasonal variations of POC, DOC and the contribution of microbial communities to the live POC in a shallow near-bottom ecosystem at the northwestern Mediterranean Sea. J Plankton Res 21:1077-1100.

Rivera-Ortega J, Thomé P (2018) Contrasting antibacterial capabilities of surface mucus layer from three symbiotic cnidarians. Front Mar Sc https://doi:10:3389/fmars.2018.00392.

Rossi F, Colao E, Martinez M-J, Klein J, Carcaillet F, Callier M, De Wit R, Caro A (2013) Spatial distribution and nutrition requirements of the endosymbiont-bearing bivalve Loripes lacteus in a Mediterranean Nanozostera noltii meadow. JEMBE 440:108-115. https://doi.org/10.1016/j.jembe.2012.12.010

Rossi S, Gili JM (2007) Short-time-scale variability of near-bottom seston composition during spring in a warm temperate sea. Hydrobiol 557 373-388. https:// doi.10.1007/s10750-0060390-y

Schweimanns M, Felbeck H (1985) Significance of the occurrence of chemoautotrophic bacterial endosymbionts in lucinid clams from Bermuda. Mar Ecol Prog Ser 24:113-120. https://doi: 10.3354/meps024113

Seed R (1969) The ecology of Mytilus edulis L. (Lamellibranchiata) on exposed rocky shores. Oecologia (Berl.) 3:277-316. https://doi: 10.1007/BF00390380

Séré MG, Massé LM, Perissinotto R, Schleyer MH (2010) Influence of heterotrophic feeding on the sexual reproduction of Pocillopora verrucose in aquaria. J Exp Mar Biol Ecol 395: 63-71. doi:10.1016/j.jembe.2010.08.014 
Souchu P, Gasc A, Collos Y, Vaquer A, Tournier H, Bibent B, Deslous-Paoli J-M (1998) Biogeochemical aspects of bottom anoxia in a Mediterranean lagoon (Thau, France). Mar Ecol Prog Ser 164:135-146.

Southward EC (1986) Gill symbionts in thyasirids and other bivalve molluscs. J Mar Biol Assoc UK 66:889-914. https://doi.org/10.1017/S0025315400048517

Stewart FJ, Newton ILG, Cavanaugh CM (2005) Chemosynthetic endosymbiosis: adaptations to oxic-anoxic interfaces. Trends Microbial 13(9):439-48. https://doi:10.1016/j.tim.2005.07.007

Taylor JD, Glover EA (2006) Lucinidae (Bivalvia) - the most diverse group of chemosymbiotic molluscs. Zool J Linnean Soc 148:421-438. https://doi.org/10.1111/j.1096$\underline{3642.2006 .00261 . x}$

Travers M-A, Miller K, Roque A, Friedman C (2015) Bacterial diseases in marine bivalves . J Invert Pathol 131:11-31. http://dx.doi.org/10.1016/j.jip.2015.07.010

van der Geest M, Sall AA, Ely SIO, Nauta RW, Gils JAV, Piersma T (2014) Nutritional and reproductive strategies in a chemosymbiotic bivalve living in a tropical intertidal seagrass bed. Mar Ecol Prog Ser 501:113-126. https://doi.org/10.3354/meps10702

van der Geest, van der Heide T, Holmer M, de Wit R (2020) First field-based evidence that the seagrass-lucinid mutualism can mitigate sulfide stress in seagrasses. Front Mar Sci 7:11. https://doi:10.3389/fmars.2020.00011

van der Heide T, Govers LL, de Fouw J, Olff H, van der Geest M, van Katwijk MM, Piersma T, van de Koppel J, Silliman BR, Smolders AJ, van Gils JA (2012) A three-stage symbiosis forms the foundation of seagrass ecosystems. Science 336:1432-1434. https://doi: 10.1126/science. 1219973

van Dover CL (2000) The ecology of deep-sea hydrothermal vents. Princeton University Press, 1412 p. https://doi.org/10.4319/1o.2001.46.8.2094

van Gils JA, van der Geest M, Jansen EJ, Piersma T (2012) Trophic cascade induced by molluscivore predator alters pore-water biogeochemistry via competitive release of prey. Ecol 93(5):1143-52. https://doi:10.2307/23213508

Vidal-Dupiol J, Ladrière O, Destoumieux-Garzon D, Sautiere P, Meistertzheim A, Tambutté E, Tambutté S, Duval D, Fouré L, Adjeroud M, Mitta G (2011) Immune innate responses of a scleractinian coral to vibriosis. J Biol Chem 286:22688-22698. https://doi:10.1074/jbc.M110.216358 
851 Ward JE, Shumway SE (2004) Separating the grain from the chaff: particle selection in suspension- and deposit-feeding bivalves. JEMBE 300:83-130. 853 https://doi:10.1016/j.jembe.2004.03.002

854 Xing J, Pales-Espinosa E, Perrigault M, Allam B (2011) Identification, molecular 855 characterization and expression analysis of a mucosal C-type lectin in the eastern oyster, 856 Crassostrea virginica. Fish Shellfish Immunol 30:851-858. https://doi: $857 \quad$ 10.1016/j.fsi.2011.01.007

858 Yuen B, Polzin J, Petersen J (2019) Organ transcriptomes of the lucinid clam Loripes 859 orbiculatus (Poli, 1791) provide insights into their specialised roles in the biology of a 860 chemosynthetic bivalve. BMC Genomics 20:820. https://doi.org/10.1186/s12864-019861 6177-0

862

863

864

865 